\title{
Identification of the Problems Faced by Madrasahs in Response to Institutional Change
}

\author{
Supa'at \\ Sekolah Tinggi Agama Islam Negeri Kudus \\ Kudus , Indonesia \\ Supaatkudus@yahoo.com
}

\begin{abstract}
Within form and its current status, the existence of madrasah actually has passed a long history in struggling for the recognition and equality. National Education System Act No. 2 of 1989 and Act No. 20 of 2003 are the basic policy, which decided by the government to meet the aspiration of political education of Muslims ummah. This study is to answer the question on how the prospects and challenges are faced by madrasah after being transformed as a policy product. This study tries to provide the answers and reveal a number of phenomenons, which particularly encountered by madrasah within its new status. To portray a full description requires with the various problems faced by madrasah, thus this study will use a phenomenological qualitative approach. Although from legal perspective the existence of madrasah is getting stronger, the research finding shows that the implementation of transformation confronts several problems, as follows: (1) management capacity, (2) curriculum, (3) lack of human sources, (4) academic orientation and the dichotomy of science, (5) context of national examination, and (6) context of regional autonomy.
\end{abstract}

Keywords-educational policy, change of status, transformation, Islamic education

\section{INTRODUCTION}

Madrasah substantively as an educational institution is the transformation and modernization of the traditional Islamic education of pesantren. Historically, this institution has already existed through experience of da'wah Islam in the Indonesian Archipelago. Although obviously it has played its significant role in educating nation society (Ummah), the existence of pesantren and madrasah throughout the history got less attention from the government. During the colonial era, the presence of pesantren and madrasah not only was not being supported, but also isolated by the Dutch government because it was considered as the emerging of the birth place of struggling ideas to against the colonial government. At the beginning of the independence era, if it was compared to the school system (public schools), madrasah still got the treatment of discrimination from the government. It can be seen from unrecognizably admitted of graduates working in the formal sector government or even continuing the higher educational level, because the graduates did not have the required competences. This such a condition encourages the Islamic scholars on continuing the struggle to get proportionate recognition from the government.

Responding to the demands and/or Muslim aspirations, the government released a Joint Decree (SKB) of three ministries in 1975 (Ministry of Religious Affairs, Ministry of Education and Culture, and Ministry of Home Affairs) whose implicit mission is the recognition of madrasah graduates to obtain the rights as in line with the public schools. This policy is the starting point of recognition and the inclusion of madrasah to the national education system. The peak recognition of the existence of madrasah by the government associated with the release of the Educational Act No. 2 year of 1989 and the Law No. 20 of 2003 about National Education System. These two regulations enable madrasah to be equal with public schools. Relatedly, with a new status as "public high schools distinctively Isamic religion", madrasah was previously known as a religious educational institution or a religious school.

As a product of policy, the change of status is expected to make madrasah become more productive and competitive. Although this change has been carried out and running for more than two decades, but in fact, until this time there is a difference of perception within implementation, especially in defining, formulating, and embodying the hallmark that might be different from other public schools. The main question that still remains unanswered or unformulated formally is what kind and how is the implementation of "education under teaching of Islam" and "education within a religious atmosphere" as the embodiment of hallmark. The difference in perception of how is the implementation of the hallmark become more complicated if it is associated with the objectives reality of madrasah as the educational institution in the context of mainstream national education. This fact then exposes madrasah into various problems and challenges in realizing the vision and goals of education.

\section{LITERATURE REVIEW}

Ross \& Bailey [1] categorized educational change based on its characteristics and objectives into three, namely reform, restructuring, and transformation. School reform refers to modest modifications in schools; school restructuring refers to substantial change in the educational process; and school transformation refers to a radical modification in the form and substance of education by reinterpreting teaching, learning, and knowledge. This definition of school transformation is appropriate when thinking about and using emerging technologies in school improvement.

The policies in education, in terms of House and Mathison (Seidman. Ed.) [2] Called as social intervention in education, which its goal is to change, and improvement. Harrington [3] also called as the tem of improvement process. Although the improvement requires the result of change, but "change" cannot be assumed to bring the improvement itself. Thus, the 
change scarcely be as "the result" of a policy is not be able to touch the substantive aspect of the policy objects but it only touches the top or just a formality. Therefore, according to Hopkins, [4] in the education context, improvement is defined as a distinct approach to educational change that enhances student outcomes as well as strengthening the school's capacity for managing change".

According to Muhammad Sirozi, [5] policy is a political compromise which is dynamic and interactive, one solution among the interests in a toughly competitive world. A similar opinion was argued by Taylor, et al., [6] Policy is a political compromise among various conflicting views about how the change run should. The aim of this compromise is reached through values negotiation between government and a number of target group's policy. Referring to this, in particular, Easton [7] emphasizes that a certain policy is actually net decisions and actions that intend to determine some values. Because of the basic importance of policy, said Easton, it exactly lies on the fact that through this, there are certain things that cannot belong to some people but they can be achieved by other particular people. Similar to Easton, Prunty [8] viewed that policy as determining values authoritatively. Therefore, the policy concept involving the use of authority, control, and validation of the value of the creating groups. The importance of value and the involvement of authority within the policy process, is also emphasized by Davis, Warhurst, and Weller, [9] defined the policy as interaction among the values, interests, and resources guided by regulation and mediated by politic.

Most writers on policy concern with a certain policy which is not always pure and rational. But, it often relates to the context, values, interests, and specific sources. While according to Sniderman and Tetlock stated, [10] factor value in a policy process is not merely to the way of look but from the basic appearance. Because it is emphasized on the particular values, so that according to Richardson [11], the making of a policy even the product itself is not a neutral policy. Thus, it is not surprising that whether a certain policy is always beneficial or detrimental on the different societies. Because of its special feature, Considene [12], viewed policy as an explanation of common value and intention.

Regulation and policies on education, regardless of its form, generally regarded as a major attraction even it is being debatable and a bit of contradiction. This is mainly because all parties are dealing with the problems of education. As stated by Dye [13], that education policy will deeply affect a wide diversity of interests, and stimulate a number of activities within group interests. Due to this, in the term of McKinnon, [14] education is everyone's business. Therefore, according to Ali Imron, [15] there are particular factors that influence on the implementation of a certain policy, as follows: (1) the complexity of various policies that have been decided; (2) the unclear formulation of policy issues and alternative solutions to policy issues; (3) the availability of potential sources that can support the implementation of policy; (4) the ability and skill of policy organizers; (5) the support of target public policy and (6) the effectiveness and efficiency of bureaucracy.
Since the issues of education is referring to the mutual interests and people's needs, so a change on education belongs to a fundamental problem which is ever and definitely linked to the culture, perception and even in many people's belief. Hence, the education experts agreed that the system and objectives of education for societies or countries are not able to be imported or exported from a certain country or society. The other opinion, as highlighted by Azyumardi Azra (Abudin Nata) [16], it must be grown and "stitched" in accordance with the shape and size of the wearers, based on identity, way of life, and values contained in the society or the country. Having considered to this view, there is no educational concept and theory that can be prevailed or even applied as a whole in terms of implementing to the different places and settings.

The difficulty or obstacle is due to the place or setting in the context of educational institutions, schools, or madrasah as the organization which have traditions or cultures that have been created and become a reference through organization, namely the organizational culture. It is important to note that based on this understanding, the success of a certain policy is not only measured by the change of the organizational structure, but more than that to reach the organizational culture change. It has been noted that "organizational culture refers to the pattern of beliefs, values and learned ways of coping with experience that have developed during the course of an organization's history, and which tend to be manifested in its material arrangement and in the behavioral of its members". [17] Brown then added that contents of an organization's culture) terdiri dari: (1) artifacts, (2) language, (3) behavior pattern, (4) norm of behavior, (5) heroes, (6) symbols and symbolic action, (7) belief, values, and attitudes, (8) ethical codes, (9) basic assumptions, and (10) history.

The change and improvement as the essence of a policy should therefore be able to change the organizational culture and its content within a process, which Harrington (1987: xiii) called as the improvement process. According to Harrington, change and improvement are two complementary factors in creating a change in a certain educational institution. It should also be pointed out that referring to Harrington's view [18], defines the improvement process as "a group of activities that complement each other and provide an environment conducive to improving performance for employees and management alike". In a management perspective, changes or policies in education particularly aim to make education activities more effective, efficient, and productive on order to gain the educational process and qualified result. Considering with the importance and its relevance in terms of the study of this dissertation, thus the description of the effectiveness, efficiency, and productivity will be discussed at the separate sub chapter.

\section{METHOD OF STUDY}

Based on the objectives of the study, the most appropriate chosen methodological is a qualitative phenomenology. The main focus of this study is the whole activities of Madrasah Aliyah as an educational institution which is the learning process as a core issue. Geographically, this study was conducted in Kudus, by considered the implementation of the 
Islamic education characteristics which taken in 29 Madrasahs Aliyah. Particularly, there are two stages analyses in this study, namely: (1) analysis of the field, and (2) analysis taken from data collection. The first stage analysis resulted from the field note [19] or fieldwork [20]. From this substance point, the analysis stage got tentative conclusions or hypotheses which taken from the observation, interviews, and documents reviews by applying inductive analysis model. The data of tentative conclusions that were obtained in the first stage analysis, then further developed in the second stage analysis that is the analysis taken from data collection. At this stage, the whole data were inductively analyzed employing the descriptive qualitative analysis.

\section{THE RESULTS OF STUDY AND DISCUSSION}

According to theories discussed above and based on data collected in the field, this study formulated the problems and obstacles faced by Madrasah Aliyah within the response to change of institutional status and the realization of its new status in the context as sub-system of national educational, in general they are divided into six main areas, as follows:

\section{A. Management Capacity}

A management capacity here that adheres to the capability of madrasah in providing various facilities needs to be well required for ongoing learning process. More specifically, the supply of main facilities and infrastructure for primary education. Most Madrasah Aliyah in Kudus, especially private ones which the learning process conducted within a lack of facilities and infrastructures have not met the quality standard yet (The Regulation of Minister of Education and Culture No. 24 of 2007). This obviously occurs because funding resources and financial support needed for this supposed aim is not quite enough. The fact and this condition become very prominent factors in most Madrasah Aliyah, particularly in several madrasahs which were born recently and/or located in suburban/rural areas. In fact, it is also important to note that such well known madrasahs must be admitted have already provided well-equipped facilities and infrastructures towards found and located in urban areas or a city center. But, in most madrasahs dealing with conducting teaching and learning process have unwell structured of the buildings both quantity and quality standard. This regards due to the high interests continuing students "education rather than paying more attention to the availability of school facilities and infrastructures.

There are three dominant factors that influence of the Muslim societies in choosing madrasah as continuing their children's studies: (1) religious motivation - by studying in madrasah means studying the Islamic education. By studying in madrasah, students' parents fully expect that someday their children can acquire a good Islamic education as well as general knowledge, so that the students' behavior can be in accordance with religious norms. (2) The education cost is reasonable. The cost is reasonable because historically these institutions as the modernization form of the traditional Islamic institutions (pesantren). Due to the sense of Islamic studies, so there is no explicitly initiative on a "transaction" related to the education cost. (3) The limitation of school capacity in public schools/madrasahs. It has been recognized that the choice of continuing to study, particularly in private madrasahs is in the second choice. This is due to the students candidates have been rejected from the well-known public schools/madrasahs, in particular they academically ineligible be accepted in any public schools/madrasahs. In addition, because of limited capacity, not all the students' candidates would be accepted.

The whole process of educational implements and teaching and learning in Madrasah Aliyah, most notably the private ones in District of Kudus, have been running on minimum financial support even more difficult to be adequate standards for the learning process. The main funding source got from students'contribution of SPP/ syahriyah which put a nominal fee (the cost range is from Rp. 50.000,- to Rp. 100.000,monthly), and from the temporal sourced from the anonymous donors who donate generously through wakaf, zakat, infaq/sodaqah. For this second type of funding source is determined by the ability and reputation of the foundation figures in tapping funds from society, especially the generous people (aghniya').

Then what about the role of government regarding with the Ministry of Religious Affairs in the face of this reality? Indeed, there have been many policies made by the government to preserve the institutional of madrasah, but as many number of private madrassahs so that these policies are less significant to change the situation. As an analogy drawn by the Director of Islamic Education from the Minister of Religious Affairs (Yahya Umar: 2005), madrasah is like the engine from the old car which must carry the heavy load. Then, in the context of this metaphor, the next steps considered by the Ministry of Religious Affairs include: (1) Maintain the engine, (2) reducing the burden, (3) changing the load into energy. These all means that the educational system has to administer to all parts of madrassah not only be centralized in one certain component part.

\section{B. Curriculum}

The structure / composition of Madrasah curriculum prior to the releasing of SKB three ministries decree of 1975 from the comparison between religious subjects and secular subject is 70:30 but afterwards the issuance of SKB three ministries decree, it has turned around to 30:70. The composition then totally turned to the extent of Law No. 2 of 1989 on National Education System which has simply clarified in the Government Regulation (PP) No. 29 of 1990. Within the Government Regulation (PP), it has been determined that madrasah has the applicable national curriculum and special characteristics which have administered in Chapter VII Article 15 paragraph (4) and (6). In addition to these provisions, the Decree of the Ministry of Education and Culture No. 0489 /U/1992 act (6) confirmed that Madrasah Aliyah is obliged to provide the learning materials at least equal to the High Schools, besides the learning materials provided by madrasah as a manifestation of Islamic characteristics. Under these provisions, Madrasah Aliyah curriculum should fully use the 
High School national curriculum administered by the Ministry of Education and Culture.

Based on these regulations, Madrasah Aliyah curriculum was already be $100 \%$ exactly the same as High School. This composition belongs to a literal translation of the formulation "at least to the same extent" as desired in the Decree of three ministries. Constitutionally, the difference of Marasah Aliyah got a new status as "Public High Schools distinctively Islamic religion". The implementation of Islamic characteristics which also runs as the differences between Madrasah Aliyah and Public High Schools, such as: First, for the subjects of Islamic Religious Education (PAI) at High Schools administered in a package of subject taught by a teacher so called a religion teacher. This is supposedly different to Madrasah Aliyah in which the material of Islamic Religious Education (PAI grove) is differentiated / divided into five subjects: (1) Qur'an Hadiths, (2) Aqeedah - morals, (3) Fiqh, (4) Cultural History of Islam (SKI), and (5) Arabic. The structure and composition of such a curriculum were started in the early of 1994, known as the 1994 "curriculum".

Second, because the materials of Islamic Religious Education have been divided into five subjects and consequently tend to provide more teaching hours. Then, for those which consider as the private Madrasahs Aliyah, they are technically added with a number of religious studies for deepening and enriching the students' competence based on the vision in each madrasah (organizational visions and / or management scholars of Madrasah Aliyah). While the duration and learning time allocation in each day between Madrasah Aliyah and High Schools are exactly same (starting at 07.00 to 13.30). This condition then confronts private madrasahs into the difficult of choices. For certain Madrasahs Aliyah, such as MA Qudsiyyah, MA TBS, MA Miftahul Falah, and MA Ma'ahid, the chosen strategies like: (1) cutting the duration and frequency of face to face in terms of the national curriculum subjects (secular) and fulfilling with Islamic studies enrichment by more concerned with the learning system of yellow books (kitab), (2) the Islamic religious subject based on national curriculum from the Minister of Religious Affairs both material or syllabus are replaced to the similar materials towards the reference from yellow books, (3) the secular subjects that are not tested in the national examination as well were not taught at all, much time allocation is presented to the lesson of yellow books. The essence of this initial concept is due to the view of private Madrasah Aliyah managers who considered that the teaching materials of Islamic education national curriculum are less important and incompatible with the identity and historical context of the birth of Madrasah Aliyah.

The main purpose of the addition and learning system is to enrich and strengthen the students ' mastery in the field of Islamic study. Even in some private Madrasahs Aliyah, such as MA Qudsiyyah, MA TBS, MA Miftahul Falah, and MA Ma'ahid, the competency and mastery of the yellow books are being superior. In this case, the MA managers realized that if teaching Islamic religious education is taught only based on the national curriculum of the Minister Religious Affairs without any enrichment, thus the MA graduates will not optimally achieve the goals, in particular with the Islamic studies. As a result, MA graduates are not much different from the High School graduates.

It is important to note that another problem related to the curriculum is the understanding of a number of scope subjects and dichotomy perspectives on studies. A certain view states that between religious studies and secular studies, madrasah / Islamic schools and secular high schools are two different entities that cannot be established due to the management of curriculum. Consequently regarding with this understanding, there are found two phenomenon within madrasah. First, the teaching of Islamic religious education in MA remains as the normative - textual. Second, educational subjects that categorized into science, in fact they are substantively separate from religious studies. This occurs especially to the enactment of the National Examination policies. Prior to the enactment of these policies, there have been attempts to combine the general science subjects with religious sciences in an integrated package.

So, the essential problems of the implementation of madrasah curriculum within the status and its position as Public High Schools distinctively Islamic religion, are: (a) limited learning time, both duration and frequency, (b) a number of subjects that should be given in order to achieve the educational goals of madrasah, so that the curriculum becomes a requirement with the loaded subjects. Based on the composition and content percentage curriculum when they are compared to secular schools, the MA curriculum is actually $130 \%$ in accordance with all the subjects the same as secular schools (according to the provisions as defined in the content standard). While, the subjects in madrasahs include into five main subjects within the allotted time covered 6 to 10 lesson hours in a week $(30 \%)$. Based on research studies towards various phenomena that raise in the field, it can be concluded that the root causes of the raising problems because: (a) the existence and a strong understanding dichotomy about studies, and (b) less proportioned understanding to the religious doctrines.

\section{Lack of Human Resources}

The characters of the birth of evolutionary madrasah are started from a non-formal religious activity at the mosque / musholla then turned into Madrasah Diniyah / pesantren and eventually developed into formal madrasahs (MI, MTs, and MA). Because madrasah has been perceived and believed as the place of religious activities, so the main factor that encourages the founders for its establishment is their greatest enthusiasm (faithful) of worship and devoted to God. Therefore, carrying out the process in developing the potentials of madrasah was run by the Islamic scholars. It has certainly been common that in the beginning of the learning process, the educational units such as buildings and rooms whether classrooms, teachers' room, or principal's room have not been concernedly designed as a place of educational activities. As a consequence, the learning process tends to be held in a certain place or a temporary building. Indeed, when almost private madrasahs are considerably established their 
Madrasah Tsanawiyah at the beginning time, they much like using the existing school buildings of MI/SD, while in other cases, Madrasahs Aliyah are likely to use the school buildings of MTs as well. Most of all, at the beginning of their establishment, physically they have not their own buildings for teaching and learning, neither other facilities nor infrastructures.

Like most other schools, the especially important to note at the first time is the availability of madrasah teachers and managers, while in terms of competency and ability are not really important to be considered. As well as the school buildings, the teachers who teach in MTs usually come from some MI teachers, for which the students of MA are commonly taught by MTs teachers from their own foundations. In simpler terms, in can be said that the establishment of new madrasahs needs lots of Islamic spirit and intention to li i'lai kalimatillah (to be devoted to the religion of Allah). Lack of human resources meant here is the importance within the educational learning process includes:

\section{1) Teachers qualifications and competencies}

It is true that the quality of education is not only determined by the teachers components, but also the students quality, facilities / infrastructure, and other instrumental factors. But one thing is for sure, all the factors will ultimately depend on the quality of teaching and learning that determined by the competence and professionalism of teachers. No matter how qualified of the instrumental input in teaching and learning process, the teachers' ability in implementing the learning process will determine the results (output) within the educational process. Through the qualified and professional teachers, they are able to make substitution and / or complement various shortcomings in other component inputs. As stated by Law No. 14 of 2005 on teachers and lecturers which said that teachers must have accumulated four competencies, namely pedagogical competence, professional competence, personal competence, and social competence.

In general, the condition of teachers at madrasah today can be grouped into three categories: (1) Teachers who are not capable / under qualification (underqualified). This means that these teachers do not obviously have teaching qualifications as authority in matters of law (Bachelor or Diploma IV). (2) Teachers who have already met the educational qualifications but they teach another field of subject which does not consider their competence (miss - match). In other words, their educational background are not required to their subjects area. (3) The teachers who are qualified or appropriate qualifications in which they teach field of subject based on their proper educational background and qualifications.

\section{2) The Managerial Skill of Madrasah Aliyah Managers}

As well as the qualified condition of the teachers, the quality of educational staff play significant role in the management of madrasah, such as the principal of madrasah and the supervisory personnel. Unfortunately, most of them are still far from the expectation for a quality educational process. The problem commonly faced by the private Madrasahs Aliyah in terms of leadership and managerial that is the recruitment process of finding the principle of Madrasah Aliyah. The primordial considerations are still very dominant and defeat the consideration professionalism. This is because almost all private Madrasahs Aliyah in Kudus in the process of establishment are not only initiated but also sponsored by founders from their own special fund, in spite of officially under the management of the foundation/ organization. It can be simply said that most private MA in Kudus called as the family business. In this context, the authority from management is very dominant including in determining who will be the next principle of MA. In many cases, the consideration of "family" is very dominant when there is determining the candidates for principle of MA, without considering the professionalism. Because it tends to be a family business, so the mechanism of change and appointment the MA principal is not really transparent. It can be seen from the period of leadership of the MA principal in which there in no limit time period. Of course, this is supposed to be less conducive to the creation of healthy competition (regeneration) to the next existence of more responsive, progressive, and innovative leaders.

In response to such condition, then it would make sense if the rate of educational progress of madrasah is quite slow without any creativity and innovative breakthroughs. In the short term, this situation supports less creation of effectiveness and efficiency, while in the long run, it will be for lack of the creation of output and outcome quality in education. So, dealing with such phenomena, it needs to develop clarified policy for the recruitment of prospective principle to get the next competent and professional candidates of the head madrasah. For example in terms of administrative qualifications, the candidates of head madrasah must be at least the graduates from bachelor or master degree (S1 or S2). In addition, all candidates must come from educational background/teaching institutions and have teaching experience becoming a teacher at least 10 years. While from the point of religious morality, the head of Madrasah Aliyah should have good integrated moral and never been involved in any violations of social morals and ethics. If these conditions can be dealt, we are expected to the next qualified education for Madrasah Aliyah.

The similar condition also refers to the quality of supervisory personnel. It is not surprising that most supervisors of madrasah are from the administrative personnel, for example the former official heads or the heads madrasah who have mutated into supervisory personnel due to the extension of civil service period (retirement age). Thus, it can be imagined how the quality of supervision must have been like. In fact, these supervisors are not much more likely playing the prominent role and performing the important functions as "the administrative inspectors". Indeed, they do not have much time to supervise all the substantial issues and teaching learning process that actually goes on madrasah educational system. In the near future, the recruitment of candidates for the next supervisors needs to be designed with the administrative requirements and highly academic qualifications. It is important to note that the supervisory 
positions are professionals who have good qualifications from administrative, academic, and religious morals.

\section{Academic Orientation and Dichotomy Study}

Recently, science and technology are growing rapidly. Having looked from the perspective of epistemology is based on the paradigm of Western positivism. The paradigm and epistemology have spawned consciously the instrumental product of science and technology which have been able to meet the needs of modern society. Methodologically, the truth is developed through the sensual empirical facts (measurable and testable) with the characteristics of truth value free. By applying this such methodology, then the obtained truth is often called as the truth profan or relative. In contrast to this truth, in terms of Islamic study and education development are depend on the transcendental paradigm. This actually means that the obtained truth can be reference to the particular information or otherwise it cannot be, both the method and the result are contrary to the message of revelation (value bond). The facts or data collection are primarilly concerned with the source of search and formulation of the truth in order not only sensual empirical but also religious belief in God. The study was born from this paradigm - the religious sciences- are considerd as sacred sciences that remain untestable truth (truth does not really need to be tested).

Based on a writer's review for the literature or textbooks used in the learning process and interviews with madrasah teachers, it draws a conclusion that dichotomy study still considerably influences the scientific knowledge taught in MA. The subjects studies in madrasah are divided into two, namely secular studies and religious studies. Religious studies are recognized as the sacred and essential studies, but secular studies are less important and considered being common studies. Another thing that led to the birth of such a dichotomy is the understanding and implementation which are not proportionate about: (1) The meaning of worship and various activities that relate to the worship for ALLAH SWT. (2) The doctrine of theology / aqeedah. In order to worship properly then be accepted by Allah - one must have a sincere belief in accordance with worshiping to Allah. As regards the understanding of this context, the science studies that are probably be necessary and lets straight someone perform good ritual behaviour are expected to be taught to students. In fact, due to the inevitability of the institution and the demands of this such regulation, both subject studies (secular and religious studies) are still being taught in Madrasah Aliyah and thus the structure of content curriculum be the local subject material.

This occurs because at the beginnning. MA is an educational institution which relies on the religious institutional with religious sciences and mission of religious da'wah as the most oriented activities. Within position such like this, it is not confusing that until today the condition of scientific and academic orientation of Madrasah Aliyah in Kudus, especially the private MA, strongly influenced by the medieval paradigm of classical Islamic thought, where Fiqh and Kalam study are dominant. Islam absolutely emphasizes the balance between the life of this world and the hereafter, worship, mu'amalah, the relationship between God and man then between man and our fellow man, indeed do not distinguish by comparing between these two. Even statistically stated, most the verses from the Qur'an have indicated the importance of mu'amalah which is much more than the affairs of another worship.

Some private Madrasahs Aliyah that have a vision and a strong religious orientation (tafaquh Fiddin - Salaf) seriously distinguish the religious sciences into several subjects. Madrasah Aliah Qudsiyyah Kudus for example, categorizes or differentiates the learning material into four groups of subjects, which are: al-Ulum al-Shari'ah (Shari'ah science / law), al-Ulum al-Lughowiyah (Language science), al-Ulum altsaqofah (social science and culture), Al-ulum al Riyadhiyah (exact science). Each group of subject has been particularly described into several sciences (see the following table). While some other Madrasahs Aliyah distinguish and classify a group of subjects appropriate to the given lesson descriptions based on the Department of Religion by added extra religious subjects.

\section{TABLE I. THE CLASSIFICATION OF SCIENCE AND} SUBJECT STUDY IN MA QUDSIYYAH KUDUS

\begin{tabular}{|c|l|l|}
\hline $\begin{array}{c}\text { N } \\
\text { o }\end{array}$ & \multicolumn{1}{|c|}{$\begin{array}{c}\text { Group of } \\
\text { Subject }\end{array}$} & \multicolumn{1}{c|}{ Branch of Science Studies } \\
\hline 1 & $\begin{array}{l}\text { al-Ulum al- } \\
\text { Syari'ah }\end{array}$ & $\begin{array}{l}\text { Tafsir al-Qur'an, b. Ulumul qur'an, c. Qiro'ah } \\
\text { science, d. Hadiths, e. Mustholah Hadiths, f. } \\
\text { Tauhid, g. Akhlak, h. Mantiq, i. Aswaja Doctrine, } \\
\text { f. Fiqh, g. Ushul Fiqh, and h. Falak Logarithm }\end{array}$ \\
\hline 2 & $\begin{array}{l}\text { al-Ulum al } \\
\text { Lughowiyah }\end{array}$ & $\begin{array}{l}\text { Nahwu - Shorof, b. Arabic, c. Balaghoh, d. } \\
\text { Muthola'ah, e. Qiro'ah (Qiro'ah Sab'ah), f. } \\
\text { Indonesian, and g. English }\end{array}$ \\
\hline 3 & $\begin{array}{l}\text { al-Ulum al- } \\
\text { Tsaqofah }\end{array}$ & $\begin{array}{l}\text { Cultural History of Islam (SKI), b. PPKN, c. } \\
\text { Economy, d. Books Arrangement, e. Trade } \\
\text { Numerical Calculation, f. General education } \\
\text { science, g.Psychology, h.Sociology, i.Geography, } \\
\text { and j. Information \& and Communication } \\
\text { Technology (ICT/TIK) }\end{array}$ \\
\hline 4 & $\begin{array}{l}\text { al-Ulum al- } \\
\text { Riyadhiyah }\end{array}$ & $\begin{array}{l}\text { Mathematics, b. Physics, c. Chemistry, and d. } \\
\text { Biology }\end{array}$ \\
\hline
\end{tabular}

\section{E. The Context of National Examination (UN)}

A discussion of the National Examination (UN) in this paper is not supposedly within context of discussing whether agree or disagree about any matters related to the implementation of UN at Madrasah Aliyah. Indeed, it could be more concerned on the effect of implementation of the UN policy towards the existence and the identity of Madrasahs Aliyah as High Schools distinctively Islamic religion. The essence of the UN policy that applies to MA is being a mandatory policy that cannot be denied due to the consequence of the merging of madrasah in the national education system. The UN policy as a part of other efforts ensures the quality of the process and educational outcomes. All parties as well as the educational managers agreed that it is impossible to the quality of education be achieved when there is no transparent standard as the benchmark norm and reference. But, the main problem is the set standards are more concerned on the results rather than the chronological process. As a result, the set standards had turned uniformly into various inputs and processes. It is essential to note when the UN orientates more towards the results in which this system is 
then applied to all educational institutions without considering the relevant level of objective reality at the micro scale of school / madrasah, several problems may rise afterwards. It is impossible to get the objective result when the use of standards qualifications and measurement tools is similar to measure objects which are totally different. When this matter is deeply analyzed into the root of phenomenon causes towards rejection of the UN policy is due to the unpreparedness of school / madrasah in facing the National Examination. In this part, the description of the influence and impact towards the implementation of the UN on the practice and learning system in Madrasah Aliyah.

First, the passing score standard. Determining passing score standards has become a necessity, but the problem is whether the passing score standard has already considered the objective reality and heterogeneity that inherent in each unit of educational institution. Moreover, the problem deals with the tested school subjects which are only six subjects from more other subjects received by the students through the educational process of teaching and learning in MA. Here, then, the question arises, is it fair enough or is this system appropriate for the students of MA in terms of process of standardization and educational outcomes by only examining the six secular subjects. In fact, Madrasah Aliyah got a new status as a high schools distinctively Islamic religion with some extra Islamic subjects taught to students.

The fact then affects a negative impact on the perceptions and behavior of students and teachers of MA. Most students are worried, while the teachers are less confident also the managers of MA management imagine a grey story and portray the worst description of the future madrasah. Many people, especially teachers and students determine, although the set standard is still far from the developed countries, indeed they are still worried if they are failed to pass the UN. The graduation standards are continued to rise year by year. For MA, this requirement is supposed to be hard, especially for the majority of Private MA. Due to highly standards, the expectation of the managers and teachers of MA is only important to the extent of school passing, no matter how much grade obtained by the students is less important.

Second, the education system and learning disorientation. Determination and restrictions on schools subjects that will be tested in the National Examination have a negative impact on the learning process in schools which mainly emphasizes on the mastery of the tested subjects. While the other subjects to be somewhat neglected and seems to be less important. Another excess is the discrimination and neglect against the teachers and other school subjects that are not being tested. The students, teachers and even parents only more focused on the tested subjects by doing various efforts which sometimes the efforts that are contrary to the fundamental values of education.

Having looked at the symptom to strengthen the position of religious subjects PAI and a number of extra subjects according to the vision of madrasah, some private Madrasahs Aliyah within category of medium and large determine the optional policies. Most private Madrasahs Aliyah in Kudus implement the policies to the local madrasah examination by testing all Islamic religious subjects that categorized into local content subjects in order to get a diploma (syahadah) from their own foundation. For large private Madrasahs Aliyah, besides the UN, all students are required to pass the madrasah exam because this is a main requirement to get the national diploma. This step which has been recognized and admitted by the MA principal is quite effective to increase students' motivation and interest to remain more serious and do not look down on another secular subjects towards the extra religious studies.

Another thing that came up with the UN policy which recently happened is the disorientation direction and learning objectives in MA. Because the system and model UN tend to measure only cognitive aspects, unfortunately, the learning process in the classroom is just concerned on the cognitive activities. In fact, the affective aspect that actually is the most important thing in shaping the character and personality of the students to be Muslim morality became neglected, or at least has less attention. Therefore, it can be seen from the various policies in Private MA for preparing students to join the UN. There are some MA which provide boarding house for their students in one to two weeks which aims "deepening" UN subject matters. Also, some Madrasahs Aliyah within three months or a semester before the UN do not exactly teach any secular subjects except for the tested subjects. In practice, these two activities are more focused on doing the exercises or answering the UN questions based on the given examples.

Third, the learning process is less meaningful. To prepare the students to face and do the National Examination, the teachers usually apply drill learning methods, where students are trained to do a number of questions that are expected to come out in the exam questions. Through this method, the teacher expects the students to get used to the exam and master a variety of techniques and tricks in terms of doing the faced questions. Learning applying this method in the classroom actually does not properly be used with the educational goals, indeed the transfer or internalization of values. On the cognitive learning models especially in accordance with this method is less able to develop the ability to think towards the level of solving problems (problem solving creative thinking). In fact, it belongs to an indicator of the achievement of a high cognitive intelligence which is as expected to the achievement of learning objectives.

Fourth, the relevance of the National Examination to the competence of Madrasah Aliyah graduates. In the context of National Examination, Madrasahs Aliyah found an unfair treatment from other parties' policy particularly referring to the specific goals and subjects tested. With only six subjects tested, whereas all subjects' sciences are grouped in a clump of PAI and extra religious sciences to the students' enrichment are not considered to be tested. Therefore, achieving the study goals from the essential aspects is not really be measured and evaluated. As a matter of fact, the subjects of PAI are actually the core material learning in order to achieve the Islamic study goals and also become the distinguishing feature of other secular high schools. 


\section{F. Context of Regional Autonomy}

Granting autonomy to the district/city government in terms of taking care of education is a form of awareness and trust of the central government to the a large group of people, especially who are considering the law in the district / city governments. In addition to increasing the relevance of education, educational autonomy also aims to improve the efficiency and equity of educational quality. But the reality in some cases, educational autonomy precisely raise new problems specifically for madrasah. As admitted and described by the principals of private MA in Kudus, educational autonomy makes madrasah become increasingly marginalized from the current district government policy. It can be seen from the government's attention towards the form of budget allocation in education. Though, there is a budget allocation to help madrasah, but unfortunately the budget allocations are taken from the budget "social assistance" because the local budget allocation for education is only reserved for the public schools. Another reason is because madrasahs are straightly administered by the Ministry of Religious Affairs, so that the educational budget allocation comes from the central government authority. From this fact then the managers of Private MA found that this is unfair and discriminating practices. The MA students as fellow citizens feel that they got discriminated against due to the rights that they are supposed to revive are lost because they study at MA. Historically, it can be said that this situation is similar to the Islamic educational institutions (madrasah and boarding schools) in the colonial era.

This fact then occurs in the field which deals with the education quality gap between schools and madrasahs, or between public Madrasahs Aliyah and the private ones. Due to the context of autonomy, the difference of educational quality between the types and the levels of education is determined by lots attention from the local government related to educational field. This concern is primarily in accordance with the ability of local government to provide facilities/infrastructure, human resources, as well as the potential empowerment (social capital) of society. Nevertheless, the MA managers have admitted that whether it is demanded to be autonomy or not, the independence of madrasah has been proved no doubt as well. They have been accustomed to developing the Islamic education without any support from the government. The MA manager's expectations seem deceptively simple that the MA students are supposed to get much sympathetic treatment as well as the high schools students particularly with the chance of tasting "cake" of local budget.

This means that, in the context of regional autonomy of Kudus District Government, it cannot be afford to actively involved in helping to resolve one of the chronic problems faced by the private madrasahs. It also can be said as an unsolved problem deals with the educational finance. Within conditions of $95 \%$ Madrasahs Aliyah in Kudus are mostly private status with the majority of students coming from the lower class like farmers or laborers. Indeed, it can be said that Kudus District Government let the private MA struggle for themselves to survive on very little government's attention.
Supposedly, as mandated by the constitution of district/municipal governments, they formally oblige the society to provide education services not just to equalization but also educational quality.

Certainly, there is a help given by the local government to the MA in Kudus. Unfortunately, when it is viewed from the number and the frequency, they are less significant in helping of supporting the quality of MA. In particular, the help given to MA is in two forms of package measurement. First, the supporting budget for physical development development is sporadic and incidental, as received by the MA NU Banat Kudus is including a language laboratory. Second, the help by providing the educators with civil servants status is supposed to help the teachers for secular subjects that tested in the National Examination, such as mathematics, economics, English, Indonesian, Chemistry and Biology teachers. More importantly, each madrasah has different quota such as two quota, one quota and no quota at all. This regards that not all MA get DPK teachers. Then for the sake of equity, there should be one teacher teaching the same subjects in other MA. Of course, this is far from ideal. It should be surely to ease the burden of Private MA and to guarantee the learning quality in order to face the National Examination. Therefore, all the subjects that tested in the UN are mostly taught by the professional teachers. Thus, as mentioned in the earlier, one of the hard problems faced by MA dealing with the UN is because the tested subject areas are taught by teachers that categorized into miss match teachers.

\section{CONCLUSION}

There are many problems faced by madrasah in response to the institutional change as a result of the policies considered by the government. Such problems can be specifically divided and grouped into three main problems, as follows:

A. Lack of resources.

This is related to the availability and adequacy of resources to the ongoing process of educational quality and the implementation of distinctively Islamic religion. Facts show that the majority of MA in Kudus (especially the private ones) are still not able to provide all necessary resources because the lack of resources.

\section{B. Lack of human resources $(H R)$.}

The process or the birth of evolutionary history and little education financial sources cause madrasah be unable to recruit and prepare qualified and competent human resources. The birth of the evolutionary process on the one hand has many benefits, because the recruited human resources are those who are actively involved at the school with the spirit of struggle and / or worship. But on the other hand, not a few of them do not meet the requirements of the minimum competencies as educational human resources (unqualified and underqualified).

\section{Institutional vision.}

Although as political and formal juridical madrassah are ingrained in the national education system, but as a matter of fact, madrasah still have two mains, the Minister of Education and Culture and the Minister of Religious Affairs. Madrasahs 
have to submit to all the regulations that issued by the Minister of Education and Culture, because in fact, madrasahs are educational legal entities. Also, Madrasahs must comply with the regulations issued by the Minister of Religion Affairs as in charge of the implementation of distinctively Islamic religion. This fact is that in practice exposes the dilemma and difficult choices faced by madrasah. The curriculum becomes overload and overburden because there are many extra subjects that should be taught. In addition, the National Examination will be hard for MA due to the objective conditions and the dilemma between autonomy and centralization (general educational activities or religious activities).

\section{REFERENCE}

[1] Ross, T. W. \& Bailey, G. D., 1994. Reform, restructuring, and transformation - terms ini search of definition which will determine our fate as a nation in the 21st century, http://Proquest.Umi.com/. Download: Desember 2015, pp 1.

[2] Seidman, E., 1983. Handbook of social intervention. Beverly Hill/ London/New Delhi: Sage Publication, pp. 323.

[3] Harrington, H. J., 1987. The improvement process: How America's leading company improve quality. New York: McGraw-Hill Book Company, pp. xiii.

[4] Hopkins, D., 2006. Every school a great school: Realizing the potential of system leadership. New York: Mc Graw Hill -Open University Press, pp. ix.

[5] Sirozi, M., 2004. Politik kebijakan pendidikan di Indonesia: Peran tokoh-tokoh Islam dalam penyusunan UU. No. 2/1989. Leiden Jakarta: INIS, 1.

[6] Taylor, S. et al., 1997. Educational policy and the politics of change. London: Routledge, pp.13.

[7] Easton, D., 1953. The political system. New York: Knopf, pp. 29-130.

[8] Prunty, J.J., 1984. A critical reformation of educational policy analysis. Victoria: Deakin University Printery, pp. 136.

[9] Davis, N.K., Warhurst, J.W.J., \& Waller, P., 1993. Public policy in Australia (2nd ed.). NSW Australia: Allen \& Unwin, pp. 16.

[10] Seidman, E. and Tetlock, D., 1983. Handbook of social intervention. Beverly Hill/London/ New Delhi: Sage Publication, pp. 3.

[11] Richardson, J. J. (Ed.), 1993. Pressure groups. New York: Oxford University, pp. 2.

[12] Considene, M., 1996. Public policy: A critical approach. South Melbourne: McMillan Educatio Australia Pty Ltd., pp. 3.

[13] Dye, T.R., 1981. Understanding public policy (7th ed.). Englewood Cliffs - New Jersy: Prentice Hall, pp.159.

[14] MacKinnon, F., 1960. The politics of education: A study of political administration of the public schools. Canada: University of Toronto Press, pp. 15.

[15] Ali Imron, 1996. Kebijakan pendidikan di Indonesia: Proses produk dan masa depannya. Jakarta: Bumi Aksara, pp. 76-77.

[16] Abudin Nata, 1999. Metodologi studi Islam. Jakarta: PT Rajagrafindo Persada, pp. 7.

[17] Brown, E.D., 1989. Organisational culture. London: Prentice Hall, pp. 9.

[18] Harrington, H. J., 1987. The improvement process: How America's leading company improve quality. New York: McGraw-Hill Book Company, pp. 11.

[19] Bogdan, R.C. \& Biklen, S. K., 1982. Qualitative research for education: An introduction to theory and methods. Boston: Allyn and Bacon, Inc. pp. 68.

[20] Guba, E. G. \& Lincoln, Y. S., 1981. Effective evaluation: Improving the usefulness of evaluation results through responsive and naturalistic approach. San Francisco: Jossey-Bass Inc. pp. 92. 